\title{
Closing Reflections: Confronting contradictions in biographies of nations and persons
}

\author{
Paul James
}

The biography of a nation is not the same as the biography of a person. That much is simple. One is about a single person's life history and the other is about the formation of a community of persons. On the other hand, analytically describing how a biographical method can be used for both persons and nations is not straightforward. The central crossover occurs in the concept of 'the social'. An individual identity, like the projection of a national identity, is a social identity. Thus, biographies, whether of persons or of nations, are specific social genealogies, social histories, social mappings - call them what you like - graphic narratives of the bios or 'ways of life' of a person or community of persons. In this understanding, 'the social' is thus not just a background context, nor is it just another dimension to be considered among others. The social does not act as the stage on which characters walk around. The social is us - as persons and communities. In this sense, the 'social context' is a complex metaphor that describes our interrelations with others and with nature, including particular spatial configurations, specific organisational contexts and distinctive self-andother understood histories, whether they be personal or national. The notion of a 'social context' can thus be a useful metaphor, but it is too often abused.

Taking this issue as its touch-point, this essay draws on the other papers presented at the Nationalism and Biography conference to explore a 'constitutive levels' approach to understanding the social biographies of both nations and persons. Based on the range of 'national' figures discussed in the present volume, two broad forms of personal-national biography can be distinguished. Both forms present us with contradictions or paradoxes. The first is the biography of a person who is at once inside a nation-state, though not necessarily a nationalist, and, at the same time, is abstracted from it through his or her intellectually driven attempt to understand the nation analytically. Here the concept of 'intellectually driven' is used broadly to encompass narrators of nations as diverse as Enoch Powell, Helmut Kohl, Richard Sulík and G. M. Trevelyan, the subjects of earlier essays in this volume. The second is the biography of a nationally framed individual who, during his or her own lifetime, was not constituted as a national person at all. Here the figures of Boudicca and King Alfred provide points of reference. In both cases, nationalists of the nineteenth and twentieth centuries were the ones 
who claimed these figures for the national canon. As Stephanie Lawson writes about Boudicca: at the time she lived, 'there were loose confederations of tribes, but beyond this there was certainly nothing resembling a "national" polity'.

Carefully navigating the difficult relation between the personal and the general here is crucial, and this is what the contributors to this volume do so well. Positing a singular layer called 'the social context' is going to leave us with many difficulties of explanation. To understand figures as complex as those discussed in this volume, we seem to need manifold layers of the social, including layers of historical reception and canonising. The present essay is developed around a number of general propositions. These are not intended to reduce each example to an instance of the general, but they do emphasise the generality of dominant patterns.

\section{Proposition 1}

Nations are abstract communities, made up of and made by people who as a community will never all meet. Yet at the same time, nations are lived-at least in their classical form - as embodied genealogies constituted in the particularities of their time (history) and place (territoriality). This tension between the abstracted and the embodied placement of the nation is the core to understanding the formation of nations, as well as its contradictions. It helps us fathom how a narrator living in a national life-world can draw upon a figure they have never met, a person who lived long ago in a world without nations, and use them to subjectively embody a nation that objectively came into existence long after the death of that person.

\section{Proposition 2}

Narrators of a nation - and, by extension, narrators of the nation (videlicet theorists) - are embodied persons in time and place, but this is in tension with the act of narrating. That is, they are constituted through all the foibles and particularities of that time and place. Yet at the same time, by virtue of their work (the act of narrating), they are at one level lifted into an abstract relation to that 'social context' in order to reflect upon it. ${ }^{2}$ In other words, they are contextualised at two levels: as a subject and as the narrator of a subject.

1 See Lawson, this volume.

2 The distinction here between 'narrators of a nation' and 'narrators of the nation' is a simple one. While they are both intellectual categories describing persons living with and for ideas, narrators of $a$ nation can be describers of a particular nation, whereas narrators of the nation are pushed to be generalising historians, comparative sociologists or social theorists. 


\section{Proposition 3}

Good biographies of such communities (nations) or such persons (both narrators of $a$ nation and narrators of the nation) require an understanding of the (contradictory) layers in tension that make their subjects what, and who, they are. To use a different metaphor, as Christian Wicke identifies in his study of Helmut Kohl, the 'biographical constellation' is full of different and competing lights.

\section{Proposition 4}

Biographies of persons written by narrators of a nation (often themselves nationalists) tend to reduce the complexity of that person to his or her 'national context'. Conversely, contemporary critics of that reductive tendency now look back from a great height upon that earlier canonising of 'national' persons and tend to reduce those nationalist narrators to intentional creators of national fictions. This is part of a trend that Jonathan Hearn identifies in his introductory essay: a post-structuralist tendency to reduce the biographies of persons to unstable constellations of discursive performance.

The argument of the present essay is that it makes no sense to choose one side or the other of the stability/instability, social formation/self-formation or structure/ agency dialectics. The essay begins with a discussion of the problems of using biography as a method, arguing that it is best understood as an orienting and organising metaphor to bring together seemingly different fields of inquiry. Then, after briefly outlining an alternative analytical method for doing social inquiry, the essay turns to discuss a series of contradictions that needs to be understood in order to develop a deeper understanding of nations, persons who narrate nations, and persons who are canonised by nationalists.

\section{Problems with Biography as Method}

Biography as conventionally understood is problematic. Mainstream biographies describe individuals as actors walking around in the world against a background context - exactly the kind of approach that I began by questioning. The subjects of biographies think about things, pick up things and relate to significant others. They make things happen in a 'they-did-this and then they-did-this' kind of way. The background context remains just that - a colourful background. This method, even when it has persons being influenced by their background and then acting, is located within the 'socialisation' lineage of identity formation. 
This lineage, including the hypodermic-syringe model of media socialisation, reduces individuals to the carriers of the narrative into which influences from the outside world are injected.

The problems with such conventional biographies are manifold. Biographies usually treat the public as a reflection of the private, with the private realm being assumed to be foundational. This is strange given that biographies are most often written about public people who project a persona. That is, for such subjects the dominant passages of the presentation of themselves in everyday life are already formed by what might be called a 'self-biofication' process. The ugliness of that neologism is more appropriate than the beauty of the modern cliché 'life is a work of art', and it is more accurate than the post-structuralist trope 'life is a series of self-inventions'. It means, in short, that it is hard to write biographies about subjects, particularly intellectuals or public figures, who are already formed in the era of biographical and autobiographical writing and selfprojection.

The usual recourse of conventional biographies to this problem is that they seek the inner truth in the inner life of their subjects. This leads to the second problem. Biographies usually overemphasise the personal, working as a lifestory of actions based on attributed motivations and feelings rather than as an integrated social story.

Third, biographies are usually based on a methodological individualism that takes the modern individual as a given category. That is, biographies are usually constitutively flat. Very rarely do they reflect upon the different senses of personhood across history or the different ontological formations that frame being a person. For example, it is important to recognise that in the case of all the biographical figures in this volume, all the 'narrators of a nation' are modern individuals, just as their nations are all modern communities, at least at their dominant constitutive level.

Fourth, biographies are usually based on retrospective understandings of where the person ended up, thus interpreting actions in terms of a naturalised final trajectory. The same thing happens in histories of nations, and it tends to distort the work of all national historians, as well as all those writers who have ever been tempted to use the term 'proto-nationalism'.

It could also be said that the descriptive narrative bias of biographies can lead to profound weakness. This tends to be the case; however, it should also be said that descriptive narrative has to be one dimension of all good biographies and social narratives. To the extent that it brings out interconnected details of life - tensions between the general and the particular, between contingency and pattern - empirical work is foundational to understanding a subject. Making 
quirky connections, the stuff of many biographies, can usefully bring out relations and references otherwise unconsidered. For example, it is Powell who gives us the phrase 'the biography of a nation', and it is the theorist of nationalism Tom Nairn who most prominently uses Enoch Powell as an archetype to distinguish his own nationalism. ${ }^{3}$ To extend the connections, Nairn played a supervisory role in both the masters and the doctoral theses by Ben Wellings, who wrote the essay in this volume on Powell. ${ }^{4}$ And, to add another connection, Enoch Powell's Saltaire 1974 speech on nationalism was written in the same town in which I spent a month in 2002 writing on nationalism and globalism, the same year in which Ben Wellings concluded his PhD research. The point is that time and place are important. Saltaire, once the centre of a global textiles empire, was in 1974 in the throes of de-industrialisation. If Powell gave that speech now, four decades later in the context of a lingering global financial crisis and a festering immigration contestation, even as a conservative, he would address a changed relationship between the national and the global imaginaries. ${ }^{5} \mathrm{~A}$ concept that was barely available in the 1970s, 'globalisation', has become by the 2000s one of the most contested concepts in political writing. Thus, instead of the context being treated as a background feature, apparently trivial parallel stories can lead us to think of the double movement of the social: context as constitutive, and persons as constitutive of their context, a movement first given reflexive momentum by Marx's notion that people make history, but not under conditions of their own choosing. It can also lead us to flat description filled with quirky facts - and this is why a good biography is hard to write.

As a way through these issues, Jonathan Hearn has in this volume used the metaphor of identity as an ecology - a dynamic balance of forces between self-making (the process of being an individual and making oneself), social categorising (the process of using categories to make people) and social organising (the process of forming of organisations to mobilise resources) ${ }^{6}$ The method works well for many purposes. It brings social context in from the cold; however, because understanding questions of contraction and tension is at the heart of this essay, there is a need here to go a little further. The following discussion sets biographies of both persons and nations within an understanding of levels of analysis as they relate to levels of doing, acting, relating and being.

3 See Nairn, T. 1973, The Break-Up of Britain: Crisis and neo-nationalism, [Second edn], Verso, London.

4 Wellings, this volume.

5 The term 'global imaginary' here comes from Steger, M. B. 2008, The Rise of the Global Imaginary: Political ideologies from the French Revolution to the global war on terror, Oxford University Press, Oxford.

6 Hearn, this volume. 


\section{Biography as Understood through Different Levels of Analysis}

Distinguishing different domains of 'the social' requires moving across different levels of analysis, but once those domains are defined the analysis begins concurrently as an empirical task and a theoretical claim about that task. The method thus begins by presuming the importance of a first-order abstraction, here called empirical analysis. It entails drawing out and generalising from on-the-ground detailed descriptions of history and place. This does not mean accepting that what the subject of a biography or a person-as-nationalist says is an adequate explanation of a particular phenomenon; however, it does take such descriptions seriously as expressive of the experience of the world.

All social theories, whether they acknowledge it or not, are dependent upon such a process of first-order abstraction. This first level either involves generating empirical description based on observation, experience, interviews or archival work - in other words, abstracting evidence from that which exists or occurs in the world - or it involves drawing upon the empirical research of others. The first level of analytical abstraction is an ordering of 'things in the world', before any kind of further analysis is applied to those 'things'. This is the level at which most biographies or national histories are written and all of the contributions to this volume are careful to ground their work in detailed empirical research.

From this often taken-for-granted level, more theoretical approaches work towards a second-order abstraction, a method of some kind for ordering and making sense of that empirical material. At the very least they occasionally move to an unacknowledged second level either to explain or to rationalise the first. As we move to this more abstract level of analysis there is good reason for agnosticism about how this is done. The steps of analysis listed below are just one possible way. Each level has both a hermeneutic dimension (a focus on the subjectivities of practice and meaning) and a structural dimension (a focus on objective patterns of practice and meaning).

The second level of analysis, conjunctural analysis, involves identifying and more importantly examining the intersection (the conjunctures) of various patterns and subjectivities of practice and meaning. Here we draw upon established sociological, anthropological and political categories of analysis such as production, exchange, communication, organisation and inquiry. This is the level of analysis at which it makes sense to map what Jonathan Hearn calls 'social organising'; however, in the account that I am presenting, 'organisation' is only one of many things that people do when they 'act'. They also produce, exchange, communicate and inquire. Hence at this level it makes sense to talk about modes of production, exchange, communication, inquiry, as well as organisation. In 
relation to biographies of persons and nations, it is not just that a nation is embedded in an organisational context (the state and its bureaucracies) or that a person works for an organisation (the state, a corporation, a religious body, and so on), it is that any given organisational context has a specific social form or intersection of forms - for example, tribal kinship, traditional patrimonialism, modern bureaucracy, postmodern hyper-rationality, and so on. Boudicca's attack upon Camulodunum, for example, ${ }^{7}$ was embedded in intersecting tribaltraditional organisational relations that included contested understandings of inheritance. Two forms of polity-community confronted each other-the tribal-traditional kingdom ruling the Iceni people and the traditional empire of Rome - and both were fundamentally different from the kind of nation-state polity that Helmut Kohl headed. ${ }^{8}$

The third level of entry into discussing the complexity of social relations, integrational analysis, examines the intersecting modes of social integration and differentiation. These different modes of integration are expressed here in terms of different ways of relating to and distinguishing oneself from others - from the face-to-face to the disembodied. Here we see a break with the dominant emphases of classical social theory and a movement towards a post-classical sensibility. In relation to the nation-state, for example, we can ask how it is possible to explain a phenomenon that, at least in its modern variant, subjectively (and contradictorily) explains itself by reference to face-to-face metaphors of blood, soil and placement - ties of genealogy, kinship, ethnicity, territory and citizenship - when the objective 'reality' of all nation-states is that they are disembodied communities of abstracted strangers who will never all meet, even by accident (see Theme 1 below).

Finally, the most abstract level of analysis to be employed here is what might be called categorical analysis. This level of inquiry is based upon an exploration of the ontological categories such as temporality and spatiality, epistemology and performativity. At this level, generalisations can be made about the dominant modes of categorisation in a social formation or in its fields of practice and discourse. It allows us to make sense of what Jonathan Hearn calls 'social categorising', the process of using categories to make people; however, much more broadly, it is only at this level that it makes sense to generalise across modes of being, and to talk of ontological formations: societies as formed in the uneven dominance of formations of tribalism, traditionalism, modernism or postmodernism (see Theme 2 below). Even the act of writing a history or biography as we know it today is a modern (or postmodern) phenomenon. A modern biography, the dominant form, is framed by an ontology of time that moves calendrically along an arrow that moves inexorably from the past to the

7 See Lawson's essay, this volume.

8 Wicke, this volume. 
present and into the future. It provides an empty line to be filled with content. Traditional (that is, non-modern) narratives of persons and communities had no such empty line to fill. Lives were not, could not, be given a biographical singularity. Persons did not live in a universe of abstract empty time that they filled with their own content; their narrators depended upon a cosmological frame to give meaning to their practices and ideas. Empty time, the leitmotiv of modernism, gradually came to overlay the power of cosmological time, particularly in Europe across the period of the late medieval and after - the time of Boudicca and King Alfred. It eventually carried through to the dethroning of those cosmological frames. This does not mean, for example, that religious temporalities and epistemologies disappear. In the case of Helmut Kohl, as Christian Wicke describes, he could believe in both the traditional truth of the Catholic Church - Jesus died for us for all time - and modern ideas of progress.

Modern time is often described metaphorically: it travels like an arrow, it is spaced like knots on a long string, and it flows like a river. This is the form of temporality that allows for historicity, biography and conceptions of progress. That is, it leaves the space for reflection upon persons moving through 'historical time' as it is measured (tautologously) across time and space. The emergence of such a level of temporality leads us in two simultaneous directions: the first is subjectivism, for example, as expressed by Immanuel Kant for whom time was the foundation of all experience. The second is objectivism, expressed by Isaac Newton in 1687 as giving the possibility of '[a]bsolute, true, and mathematical time, of itself, and from its own nature, [flowing] equally without relation to anything external'. ${ }^{9}$ This had a foundational effect on modern biographies as they developed in the centuries that followed. In relation to the nation-state, it was Benedict Anderson via Walter Benjamin who made the extraordinary analytical breakthrough here to recognise that without modern time, the formation of nation-states was not possible. ${ }^{10}$

The discussion is only intended to give a minimal working sense of the method, sufficient that we can now turn to analysing the lived contradictions in the intertwined biographies of persons and nations. While the conceptual material of the levels approach will be there in every sentence, in seeking to track the contradictory intersections of levels, the technical referencing will largely disappear into the exemplification of the tensions. Tom Nairn, for example, evoked one lineage of tension when he described nationalism as Janus-faced. The nation, he said, is the modern Janus, with one face looking forward along the passage to modernity but forced to endure violent upheaval, while the

9 Both examples, including the quote, are from Kern, S. 1983, The Culture of Time and Space, 1880-1918, Harvard University Press, Cambridge, Mass., p. 11.

10 Anderson, B. 1991. Imagined Communities: Reflections on the origin and spread of nationalism, [Second edn], Verso, London. 
other face desperately glances backwards to the reassuring remnants of past traditions. ${ }^{11}$ The following section develops this notion of contradiction in relation to a series of interconnected themes.

\section{Theme 1. Abstraction and Embodiment}

The tension between abstraction and embodiment is no more clear than in the lives of writers. Narrators of persons and nations work from a position of disembodied abstraction through the medium of print while simultaneously they either call upon embodied relations or attempt to enact embodied connections. This tension is at the core of their identity. That is, in their capacity of being writers - the writer qua writer-intellectuals are relatively lifted out of the constraints of time and space, while in their broader identities as persons their bodies keep them firmly in place (see Proposition 2). This is similarly one of the bases for drawing connections between the objective abstraction of the national community and the flesh-and-blood citizens of any particular nation-denizens both dead and alive (see Proposition 3).

Stephanie Trigg in her book Congenial Souls evokes this tension beautifully. She describes how, long after Geoffrey Chaucer's death in 1400, and across the abstracting distance of time and space, writers, biographers and critics wanted to complete his unfinished poems, to talk with him, and even to be intimate friends with the man, Geoffrey. In general, their homo-social longing became ever stronger despite the distancing of the modern arrow of time - that is, until the middle of the twentieth century when something gradually changed. ${ }^{12}$ Expressed more generally, conversing with dead authors across separated times is commonplace in academic literature, just as drawing flesh-and-blood connections across the discontinuities of history is common in the archives of those who contribute to writing their nations into being. (It is only more recently that this has been somewhat challenged-but that is a whole other story.)

In one of the talks given at the symposium from which this volume began, Chris Bishop used the biography of the long-dead Alfred the Great to suggest that the bio-nation had been invented. The biography, he said, involved 'a deliberate attempt to misremember' ${ }^{13}$ My argument goes in a contrary direction. It suggests that the process of what might better be called '(mis)representation' has, in these cases at least, little if nothing to do with personal intention, much less with

\footnotetext{
11 Nairn, The Break-Up of Britain, Ch. 16.

12 Trigg, S. 2002, Congenial Souls: Reading Chaucer from the medieval to the postmodern, University of Minnesota Press, Minneapolis.

13 Bishop, C. 2011, Alfred the Great: reimagining an Anglo-Saxon king, Paper presented at European Nationalism and Biography symposium, ANU Centre for European Studies, Canberra, 15 December 2011.
} 
intentional falsification. Its basis can be found deep in the contradictory nature of nations and the tensions involved in writing about nations. When Alfred Bowker, writing a biography of Alfred the Great as a progenitor of the English nation, says that 'Alfred's mighty heart throbbed into every vein of the nation's organism', ${ }^{14}$ Bowker is being carried along by the abstracting/embodying possibilities of his means of inquiry - in particular, writing. He believed that it is simply true that Alfred was a progenitor of the nation, and, like Michelangelo, said to be the first Western artist to have a biography published about them while they are still alive, Bowker wrote as if he was simply finding the figure that was already present in the eternal stone of history. He believed, as many did across the century that stretched from the 1870s to the mid twentieth century, that the nation is continuous from the deep past to the present. For Bowker, the ties from Alfred to Victoria were clear: 'the sign and token of it was that blood of Alfred still ran in the veins of her Most Gracious Majesty Queen Victoria.'15 We reflexive (post)moderns, constituted in a world that forces us to reflect on questions of social being in new ways, are the only ones who are not so sure.

Other processes also draw embodied connections. 'Being there' with Alfred and Victoria is of course not possible in a literal sense. But it is possible in a literary sense. And it is possible by reliving or re-enacting the past. 'Walking with' (as a lived written metaphor) or 'walking in the footsteps of' (as an embodied re-enactment of the past) are both common lines of performance. Alastair MacLachlan's stunning essay in this volume describes the phenomenon of 'being there' through walking. ${ }^{16}$ Putting one foot in front of the other is never simple if you think about it too much. Alastair elaborates the consequences for G. M. Trevelyan of re-walking Garibaldi's route across southern Italy and Sicily, and using the embodied experience as a means to writing about him. As MacLachlan tells us: 'By reliving and writing Garibaldi's story, Trevelyan, the frustrated political activist, acquired a second, adventitiously heroic, identity, fusing his own persona with his protagonist and his protagonist's agency with a collective Italian agency: the personal and the national.' ${ }^{17}$

It is only a short distance from re-enacting the 'being there' to writing about 'wanting to be there' and reconstructing who is there at the same time. While Alastair was giving his paper at the conference, I searched the Web by wireless connection and found a contemporary blog from October 2011 by Peter G. Shilston. He describes his response to the re-walking. 'I have always thought this would be the most unforgettable of holidays: a walk across Sicily with Bertrand Russell and G. M. Trevelyan; both at the time young men at the height of their

14 Bowker A. 1902, The King Alfred Millenary, Macmillan, New York, p. 6, quoting Frederic Harrison from 1888 .

15 Ibid., p. 13, citing Bishop Creighton.

16 MacLachlan, this volume.

17 Ibid. 
powers' (emphasis added). ${ }^{18}$ It is telling that Peter G. Shilston describes himself as an 'English writer, lecturer, teacher, now retired'. He has immediately given us both his nationality and his vocation as writer. And when quaintly he uses the term 'powers' he is referring both to the bodies and to the writing of his cultural heroes.

The theme of making one's national and personal identities by walking and writing carries through into Christian Wicke's essay on the personal nationalism of Helmut Kohl. Wicke's essay references the walk by Kohl from the Hitler Youth camp, and the journey back along the Palatine wine route on the Rhine. Walking across war-ravaged Germany has since become a common reference point in Kohl's and Germany's biographies. It should be no surprise, then, in a common parallel, that Kohl wrote his doctorate (1958) on the political restoration of the Palatinate. This is, on the one hand, one of those quirky facts about a particular person that makes for an emblematic biography and, on the other hand, part of a pattern of embodiment/abstraction that afflicts all narrators of nations. In one sense, given the period that we are talking about, it is probably accurate to say that Helmut Kohl exploited his (auto)biography to project his vision of Germany into the public. At the same time - in the sense for which I am arguing - it is no accident that such a technique of 'biofication' in the name of the nation had become both available and widely used. Both Helmut Kohl and Enoch Powell are masters of the process. Stephan Auer's essay on Richard Sulík in this volume suggests that Sulík did not have their naturalised skill. ${ }^{19}$

\section{Theme 2. The Modern and the Traditional}

The tension between the modern and the traditional is palpable in the nationstate. The most important contemporary theorists of nationalism all write of nations as being a modern phenomenon. ${ }^{20}$ Indeed, nation-states as a formation have no longer history than the end of the eighteenth century. States have a long history and modern nations go back a little further than nation-states, but there are no prominent primordialist theorists of the nation left writing today who suggest that the nation as we know it goes back continuously into a pre-modern past. ${ }^{21}$ Despite this relative scholarly consensus, the nation-state

18 See <http://petergshilstonsblog.blogspot.com.au/2011/10/g-m-trevelyan.html> (viewed 15 May 2012).

19 Auer, this volume.

20 Anderson, Imagined Communities; Gellner, E. 1983, Nations and Nationalism, Blackwell, Oxford. Even Anthony D. Smith is a modernist theorist; see Smith, A. D. 1986, The Ethnic Origins of Nations, Basil Blackwell, Oxford; Smith, A. D. 2001, Nationalism: Theory, ideology, history, Polity Press, Cambridge, 2001.

21 Tom Nairn notwithstanding. Even when he writes himself in that tradition, he is doing so with a touch of irony derived from a reflexive modernist stance. He writes of himself: ‘Formerly a left half-back (reserves) with Team Modern's one-world economania, Tom Nairn switched sides in the 1990s and tentatively joined the neo-primordialists, at least for the after-match discussions.' Nairn, T. and James, P. 2005, Global Matrix, Pluto, London, p. 7. 
remains caught in Janus-faced tension between its objectively modern formation and its subjectively generated ideologies of deep traditional roots (to re-render Tom Nairn's metaphor). It is partly because, rather than replacing traditionalism in a revolutionary and epochal shift, modernism emerged unevenly and across a long period of change and upheaval as the dominant ontological formation. These practices and subjectivities of modernism have come to interconnect the globe at one level, but they did not change everything or completely sweep aside earlier formations. Hence, there is a phenomenal sense of deep continuity. On the street in the 'old' nation-states of Europe there is still a dominant sense that their nations have deep roots in history even if the political birth dates of their nation-states can be given as more recent: 1789, 1861, 1871, and so on.

This tension between modernism and traditionalism is strong but strange. In times and places which can be characterised by an overriding dominance of an ontology of traditionalism - places such as England in the seventeenth centurytradition was self-authenticating. It was not something for which arguments are needed to give it legitimacy. Arguments about the proper ritualistic or political way to do things tended to be over the interpretation of that tradition, not over its ontological standing. In comparison, the kind of desperation that we find in some nationalists like Enoch Powell to re-establish the 'continuous' force of the traditional requires, counter-intuitively, a lifting into the modern. That is, it is only with the dominance of modern understandings and practices that the defence of tradition becomes variously an imperative (for many conservatives) and a limitation to be vigorously argued against (for many liberals).

The intersection of traditionalism with modernism, for example, in the nineteenth century - the time of the formation of nation-states - brought with it tensions between, on the one hand, cosmological embodiment held in the hands of God or Nature (as traditional subjectivities and practices) and individualised personhood linked to an emerging and universalising nation imaginary, on the other (as modern subjectivities and practices). Hence, when the good liberal G. M. Trevelyan writes descriptively as a historian about Mazzini, he is able to understand that Mazzini is simultaneously a nationalist, a cosmopolitan and God-oriented. For Mazzini, Italy is God-given; therefore it does not matter that most 'Italians' do not speak Italian-'nothing is more natural'. ${ }^{22}$ This is not so easy for a modernist theorist to explain. In the same way, without a capacity to understand internal and social contradictions, it is otherwise difficult to explain how liberals can be nationalists, and how nationalists can be cosmopolitans or internationalists. Here strange alignments can be found between Mazzini, Trevelyan and Richard Sulík. ${ }^{23}$

22 See MacLachlan's essay, this volume.

23 On the last, see Auer's essay, this volume. 


\section{Theme 3. The Nation, the Person and an Emerging Global Imaginary}

The tension between the national and the global is also patterned in what would seem, from a contemporary commonsense, to be peculiar. On the street today in most places in the world - to the extent that people think about issues about the relation between the national and the global - there is a taken-for-granted sense that globalisation is antithetical to the nation-state. This tension, in Christian Wicke's terms, has been normalised. We might say (paradoxically) it is 'a globalised normality' that nation-states should seek to find their own integrity under the pressure of global change. Until recently it was a common academic position that globalisation was an unmitigated threat to the sovereignty of the nation-state. The approach presented here allows us to see that there is certainly a tension between them, but the assumption that globalisation is an unqualified threat to the nation-state is completely unfounded. It depends. The tension between them works predominantly within a common ontological formation: the modern.

To the extent that we do find ontological contradictions between the national and the global it is where, at one level, postmodern economic practices have changed the nature of time and space such as through the derivatives market based on contracted deferral of time and value; and where these come into contention with a continuing level of modern practices of nation-state building such as the territorial boundary maintenance of old-style state borders. This is currently handled by ultra-management of embodied globalisation across old borders (namely, the regulated movement of immigrants and refugeesEnoch Powell would be pleased) and the counter-deregulation of disembodied globalisation, particularly exemplified by the movement of capital (Richard Sulík would applaud).

A generation earlier, the uneven emergence of this contradiction helps us to understand how, for example, Enoch Powell could be a fervent critic of open immigration policies as evidenced by his 1968 'Rivers of Blood' speech (thus defending the modern bounded nation), a defender of British territories in the Falklands (defending the modern globalising empire), a free-market radical (open to the movement of global capital as long as it does not impinge on the 'embodied' cultural nation), and at the same time an advocate of unilateral British nuclear disarmament (a critic of abstracted political extension to the extent that is not grounded in historical and continuing relations of modern power). It was a confusing and contradictory time - which is true of all modern periods for those who live through them.

This is not to say that the nation-state in the present is not under enormous pressure. Nevertheless, the national and the global grew up together. In 
the nineteenth century, the nation-state was constituted within a broader universalising social imaginary. It was a different and emerging global imaginary linking race and nation, organised at that time in imperial terms. Chris Bishop's talk emphasised the pre-eminence of the national in the nineteenth century, but what if at that time the national was also caught in a universalising context? I would argue that it was. The other side of the emergent dominance of the national at that time was that the national was an unstable category mixed with globalising considerations of race. We only need to return to the 1902 biography of Alfred the Great to find confirming evidence: 'Alfred is, and will always remain, the typical man of our race, call him Anglo-Saxon, call him American, call him Englishman, call him Australian - the typical man of our race at his best and noblest. I like to think that the face of the Anglo-Saxon is the face of Alfred.' ${ }^{24}$ Imagine that being said today. It relates to the later racenationalism of Trevelyan in his 'holiday among the Serbians' where he sees Serbs as bringers of freedom to Kosovo. ${ }^{25}$ In passing, we can say that this relates to a form of nationalism that is never discussed in the literature: 'Other-projected nationalism' - that is, the romantic projection of the nationalism of somewhere else (linked only implicitly to the naturalisation of one's own nation).

\section{Theme 4. Gender and the Body of the Nation}

Gender and the uneven link to the body politic form another relevant theme. Stephanie Lawson's essay on Boudicca in this volume reminds us at least implicitly that in searching for the real person we do not search for Boudicca's face - mythological or actual. The same can be said of Joan of Arc, Marianne, Britannia, Liberty, and the other female figures who became iconographic carriers of different national bodies politic. In comparison, recall the quote about Alfred the Great: 'I like to think that the face of the Anglo-Saxon is the face of Alfred.' It seems that the author has no trouble imagining an actual face that at the same time can become stretched across time and other bodies, but it is not the face of the nation, but it is a face that can exemplify racial commonality. If we turn to another historian writing about the same time, we get a clue as to the gender difference here. Writing in 1915, Basil Edward Hammond is concerned about the continuity of the nation given the death of actual persons:

A community or a body politic retains its personal identity complete only from the death of one of its members to the death of the next; and as soon as all its members are dead its existence as a body consisting of certain definite persons is entirely ended. But through the space of thirty years, for which a generation remains in its prime and is not superseded by its

24 Bowker, The King Alfred Millenary, p. 9, quoting Sir Walter Besant.

25 See MacLachlan's essay, this volume. 
sons, the persons gathered in a group for common purposes remain for the most part the same. Thus the lifetime of a community or body politic is about thirty years [emphasis added]. ${ }^{26}$

The telling phrase here is 'personal identity'. In contrast, even at a time when the state was still being theorised in embodied terms as having a personality, ${ }^{27}$ Hammond, like others, found it somewhat easier to deal with the abstraction of the state than the abstraction across time and embodiment of politycommunities. He did this through invoking the legal doctrine initiated, he said, in the seventeenth-century age of treaty-making states. The doctrine suggested that the word 'state' can be 'adopted as a technical name for any succession of bodies politic which transmit rights and obligations from generation to generation'. For states, Hammond confidently concluded, 'bear no relation to concrete things' ${ }^{28}$ Thus, his approach becomes thoroughly confused. The state is strangely conceived as immaterial because it is hard to form in the mind as a 'complete image' and the body politic is strangely conceived as its opposite and reduced to a perceptible body of bodies:

A body politic, on the other hand, may be a perfectly concrete thing. All the members of a German tribe, or of a Greek city, or of the modern republics of Andorra or San Martino could, or can, be seen at a glance; the German tribesmen could all be heard at once if they murmured disapproval, or the citizens of Athens if they shouted or groaned...And beyond that every body politic...is like a concrete thing in its capacity for acting as if it were a single person. ${ }^{29}$

Here the biography of the person and the nation becomes one in the figure of the body politic. But who can best stand in for that generalised body? It is not a person with an actual face - even Napoleon Bonaparte, George Washington and Che Guevara, despite their iconic status, cannot become figures that stand for the body of the nation. Male figures with that capacity become figures of fun: Uncle Sam and John Bull. It is the female figure, mythologised and abstracted across history in a way that leaves behind her embodied particularity, which for a period in history can join the biography of the person and the biography of the nation. England for Enoch Powell is female. In his words, cited by Tom Nairn, 'the nationhood of the mother country remained unaltered through it all...England underwent no organic change as the mistress of a world empire' ${ }^{30}$ Similarly, in Tennyson's poem (1859), Boudicca is timeless: she is the figure

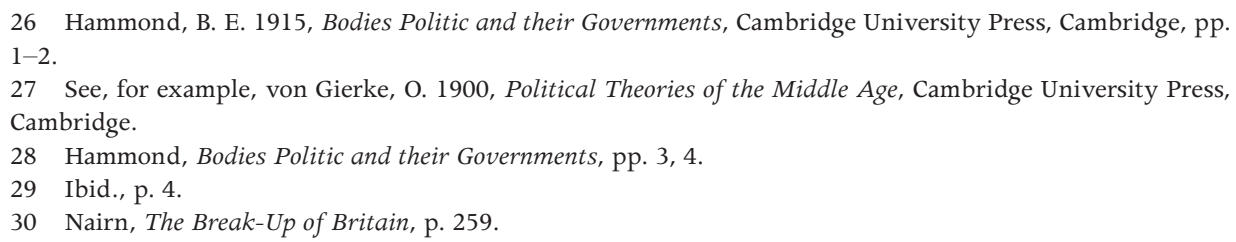


'standing loftily charioted'. In William Cowper's poem 'Boadicea: An Ode' (1782), she is the princess who is not described. In the first two lines quoted below, we are not there, but it is as if our aged eyes could respond with tears:

Princess! if our aged eyes

Weep upon thy matchless wrongs,

'Tis because resentment ties

All the terrors of our tongues.

'Rome shall perish' — write that word

In the blood that she has spilt;

Perish, hopeless and abhorr'd,

Deep in ruin as in guilt.

The poem concurrently links the tropes of the abstract ('write that word') and the embodied (spill that blood). It brings us full circle to the relation between the abstract and the concrete of the first theme and what it means to write. It also returns us in a different way to Enoch Powell's 'Rivers of Blood' speech. That talk had its power both because it used tropes of the body in history to carry his political message in way that it 'spoke' to a significant minority of Britain and because it was carried nationally by the power of 'print capitalism', to use Benedict Anderson's term. The speech was carried across the nation on the machine of the dominant modes of communication and production.

\section{Conclusion}

Theorising the nation benefits greatly from understanding both the biographies of the narrators of nationalism and the biographies of the theorists of nationalism. In conclusion, we might well ask why both the nationalists discussed in this volume and the key theorists of nationalism are caught in a tension between the centre and the periphery. In Tom Nairn's theory of nationalism, the uneven development of the dominant mode of production, capitalism, extended through the pressure of imperialism on the periphery and led intellectuals of the new middle class to defend themselves against empire in the name of the nation. 'The new middle class intelligentsia of nationalism had invited the masses into history; and the invitations had to be written in a language that they understood.' ${ }^{31}$ This meant that the world was simultaneously unified and divided (Theme 3): 'Capitalism, even as it spread remorselessly across the world to unify human society into one more or less connected story for the first time, also engendered a perilous and convulsive fragmentation of that society. ${ }^{\prime 2}$ The intellectuals of the nation were similarly divided both politically and in themselves. In political

31 Ibid., p. 340.

32 Ibid., p. 341. 
terms, some travelled along the pathway to become nationalists themselves: being conservative (Powell's national closure and Kohl's Catholicism) or liberal (Kohl's and Trevelyan's liberal nationalism) tended only to make a difference to the content of that nationalism. And some, particularly after the 1980s, came to treat nations as social inventions or more adequately as social fabrications. In 'seeing through' the process of nation formation, they became sceptics of its commonsense power.

In personal terms, theorists of the nation came to be divided against themselves. Whether nationalist or sceptic, the most important theorists of nationalism found themselves theorising the centre from an emotional periphery. The 1970s and 1980s were an incredible couple of decades in which most of the important work on theorising nationalism was written, and all the key theorists were outsiders who, through various means, came to confront the central commonsense of their time: Gellner, Nairn, Smith, Hobsbawm and Anderson. Jonathan Hearn is no different. Apart from Nairn and Hearn, they all tended to move to the centre, but none ever felt at home. Jonathan moved to Scotland. Tom Nairn remained a Scottish outsider who travelled to a series of peripheries including Prague on the Eastern periphery and then Melbourne, part of a southern colony; interestingly, Enoch Powell also had a sojourn in Australia. Nairn wrote The Break-Up of Britain in chosen exile from the place of his birth. Ernest Gellner was a Jewish outsider born in Paris, raised in Prague (now in the Czech Republic). Benedict Anderson's academic life was lived at Cornell, the centre of the New Empire, but he was born in China, and is now more at home in Thailand than in the United States. Anthony Smith is a Jewish outsider, like Hans Kohn, Sir Isaiah Berlin, Elie Kedourie (born in Baghdad), Ernest Gellner, George Mosse, Eric Hobsbawm (born in Alexandria in 1917 and raised in Vienna). They were all émigrés of one kind or another.

Thus, we can say that the nation and its theorists, and therefore the biographies of nations and persons, are intertwined. But it is not a simple process. The concept of writing biographies of such different phenomena-a community and a person - cannot be taken as a self-evident process based on a quaint homology. Like all histories, it can be done well or, as is more likely, written as various shades of badly. When it is done well, as evidenced by the essays in this volume, biography opens up new lines of insight. 